\title{
molecules
}

ISSN 1420-3049

www.mdpi.com/journal/molecules

Review

\section{Action of Natural Products on P2 Receptors: A Reinvented Era for Drug Discovery}

\author{
Robson Faria ${ }^{1}$, Leonardo Ferreira ${ }^{1}$, Rômulo Bezerra ${ }^{1}$, Valber Frutuoso ${ }^{2}$ and Luiz Alves ${ }^{1}$,* \\ 1 Laboratory of Cellular Communication, Oswaldo Cruz Foundation, 4365 Rio de Janeiro, Brazil; \\ E-Mails: robson.xavier@gmail.com (R.F.); leonardobraga12@gmail.com (L.F.); \\ romulo@ioc.fiocruz.br (R.B.) \\ 2 Laboratory of Immnopharmacology, Oswaldo Cruz Foundation, 4365 Rio de Janeiro, Brazil; \\ E-Mail: frutuoso@ioc.fiocruz.br \\ * Author to whom correspondence should be addressed; E-Mail: alveslaa@gmail.com; \\ Tel.: +55-21-2562-1809; Fax: +55-21-2562-1772.
}

Received: 7 September 2012; in revised form: 12 October 2012 / Accepted: 24 October 2012 / Published: 1 November 2012

\begin{abstract}
Natural products contribute significantly to available drug therapies and have been a rich source for scientific investigation. In general, due to their low cost and traditional use in some cultures, they are an object of growing interest as alternatives to synthetic drugs. With several diseases such as cancer, and inflammatory and neuropathic diseases having been linked to the participation of purinergic (P2) receptors, there has been a flurry of investigations on ligands within natural products. Thirty-four different sources of these compounds have been found so far, that have shown either agonistic or antagonistic effects on $\mathrm{P} 2$ receptors. Of those, nine different plant sources demonstrated effects on P2X2, P2X3, P2X7, and possibly P2Y12 receptor subtypes. Microorganisms, which represent the largest group, with 26 different sources, showed effects on both receptor subtypes, ranging from $\mathrm{P} 2 \mathrm{X} 1$ to $\mathrm{P} 2 \mathrm{X} 4$ and $\mathrm{P} 2 \mathrm{X} 7$, and P2Y1, P2Y2, P2Y4, and P2Y6. In addition, there were seventeen animal sources that affected P2X7 and P2Y1 and P2Y12 receptors. Natural products have provided some fascinating new mechanisms and sources to better understand the $\mathrm{P} 2$ receptor antagonism. Moreover, current investigations should clarify further pharmacological mechanisms in order to consider these products as potential new medicines.
\end{abstract}

Keywords: P2 receptors; natural products; antagonists 


\section{Introduction}

Natural products have long been used in traditional Western and Eastern medicine, and they are being actively pursued for drug therapies today. Natural products, which are derived not only from plants, but also from fungi, bacteria, and marine organisms, present distinctive characteristics in their secondary metabolites [1]. The unique properties of these secondary metabolites are often involved in defense and interaction with the environment, and as such they have often given rise to extraordinarily useful drugs, such as penicillin and morphine. These secondary metabolites, which the body can properly digest and process, have been and will likely continue to be, a rich source of alternatives to synthetic drugs [2]. Several factors have facilitated the search for natural products as potential new drug therapies. These factors include, but are not limited to, isolation techniques, such as spectroscopic, chromatographic, biosynthetic, and synthetic methods, and the fact that these isolates can now be obtained by synthetic or combinatorial chemistry and molecular modeling [3-5]. These advances have allowed for the investigation of natural products to become much easier and more time efficient as a source of therapeutic strategies.

One relevant area of investigation is the group of ionotropic (P2X) and metabotropic (P2Y) receptors, which have been found in all studied cells so far. These purinergic receptors, also known as P2 receptors, are crucial for the normal function of an organism, and they have been associated with some disease processes, such as rheumatoid arthritis [6], pain [7,8], and cancer [9] development. In the search for understanding the role of $\mathrm{P} 2$ receptors in these diseases, selective agonistic and antagonistic ligands have been designed and used as therapeutic agents and pharmacological tools [10]. In this context, many effective ligands have been found, but selective targeting of some receptor subtypes still remains elusive. This is the case for P2Y4, P2X2, and P2X5 receptors, where no such ligands have been discovered. This article focuses on some of the basic properties of these P2 receptors and the natural products that act on them as either agonists or antagonists. Herein, we discuss and give evidence of the large potential of natural products as possible modulators of P2X and P2Y receptors.

\section{The P2-ATP Activated Receptors}

Since the 1970s, it has been clearly demonstrated that ATP and other analogues are extracellular messengers, acting on purinergic receptors. ATP can be released without cell lysis by specific mechanisms such as: exocytosis, $\mathrm{ABC}$ transporters, and membrane channels (e.g., pannexins, connexins, maxi-anion channel, and others) $[11,12]$. Once in the extracellular fluid, nucleotides can activate the $\mathrm{P} 2 \mathrm{X}$ and $\mathrm{P} 2 \mathrm{Y}$ families of purinergic receptors. The $\mathrm{P} 2 \mathrm{X}$ group comprises of seven inotropic receptors found in mammalian cells: P2X1, P2X2, P2X3, P2X4, P2X5, P2X6, and P2X7. The P2Y family is composed of metabotropic receptors, having eight subtypes in mammalian cells: P2Y1, P2Y2, P2Y4, P2Y6, P2Y11, P2Y12, P2Y13, and P2Y14. The P2Y1, P2Y2, P2Y4, P2Y6, and $\mathrm{P} 2 \mathrm{Y} 11$ receptors are coupled to Gq, activating phospholipase C- $\beta$. The P2Y12, P2Y13, and P2Y14 receptors are coupled to $\mathrm{Gi}$, inhibiting adenylyl cyclase. The P2Y11 receptor has the unique property of coupling with both $\mathrm{Gq}$ and Gs.

In general, the $\mathrm{P} 2 \mathrm{X}$ receptors are more structurally restrictive than $\mathrm{P} 2 \mathrm{Y}$ in agonist selectivity. There is a cross-reactivity of $\mathrm{P} 2 \mathrm{Y}$ receptor probes with $\mathrm{P} 2 \mathrm{X}$ receptors, meaning that some of these probes are 
not altogether selective. More specifically, ATP acts as the active ligand for P2X receptors, whereas in addition to ATP, P2Y receptors respond to naturally occurring nucleotides such as UDP, ADP, UTP, and UDP glucose. Among P2X receptors, subtypes P2X2, P2X4, and P2X7, in the presence of millimolar ATP concentrations and prolonged activation time, form a nonselective pore with a cut of up to $900 \mathrm{Da}$, depending on cellular type and specie analyzed [13]. So far, it is an open question whether these ion channels dilate or activate another protein responsible for high conductance channels to allow the passage of small molecules, such as Lucifer yellow, Yo-pro, and propidium iodide. Up until now, there have not been specific compounds to discriminate between low and high conductance channels [13,14].

So far, less than one hundred natural products have been identified that act on P2 receptors. They are divided by species and classified as being of animal, plant, or microorganism origin as described in next sections.

\section{Natural Products from Plant Sources Acting on P2 Receptors}

Among all types of natural products, plant extracts have received the greatest attention until now. In this section, we describe and discuss plant extracts that act by modulating the activity of P2X and P2Y receptors. As can be seen in Table 1, there are three purified compounds and seven crude extracts derived from from plants. As their number is small, we will provide a more detailed description of their effects.

Table 1. Natural products from plant sources.

\begin{tabular}{|c|c|c|c|c|}
\hline Compound & $\begin{array}{l}\text { Receptor } \\
\text { Type }\end{array}$ & Effects $\left(\mathrm{IC}_{\mathbf{5 0}} / \mathrm{EC}_{\mathbf{5 0}}\right) *$ & Tested Model & Reference \\
\hline Mustard oil & $\mathrm{P} 2 \mathrm{X} 3$ & $\begin{array}{l}\text { Participation in sensitization in } \\
\text { nociceptive neurons following MO } \\
\text { application to the tooth pulp. ND }\end{array}$ & $\begin{array}{l}\text { Male Sprague-Dawley } \\
\text { adult rats }\end{array}$ & {$[15]$} \\
\hline Sodium Ferulate & $\mathrm{P} 2 \mathrm{X} 3$ & $\begin{array}{l}\text { Decreases participation of these } \\
\text { receptors in pain after primary sensory } \\
\text { afferent chronic injury ND }\end{array}$ & Rat dorsal root ganglion & [16] \\
\hline Tetramethylpyrazine & $\mathrm{P} 2 \mathrm{X} 3$ & $\begin{array}{l}\text { Inhibition of depolarization, burn } \\
\text { injury pain and neuropathic pain } \\
\text { induced by } \alpha, \beta \text {-methylene-ATP ND }\end{array}$ & Rat dorsal root ganglion & {$[17-20]$} \\
\hline Puerarin & $\mathrm{P} 2 \mathrm{X} 3$ & Impairment of neuropathic pain ND & $\begin{array}{l}\text { Dorsal root ganglion } \\
\text { neurons }\end{array}$ & {$[21,22]$} \\
\hline Emodin & $\mathrm{P} 2 \mathrm{X} 2 / 3$ & $\begin{array}{l}\text { Inhibition of the transmission of } \\
\text { neuropathic pain stimuli ND }\end{array}$ & Sprague-Dawley male rats & {$[23]$} \\
\hline Emodin & $\mathrm{P} 2 \mathrm{X} 7$ & $\begin{array}{l}\text { Inhibits ATP/BzATP-activated P2X7 } \\
\text { receptor } \mathrm{IC}_{50}=200 \mathrm{nM} \text { (cell death) }\end{array}$ & $\begin{array}{l}\text { Rat peritoneal } \\
\text { macrophages }\end{array}$ & {$[24]$} \\
\hline Emodin & $\mathrm{P} 2 \mathrm{X} 7$ & $\begin{array}{l}\text { Inhibits } \mathrm{ATP} / \mathrm{BzATP} \text {-activated P2X7 } \\
\text { receptor } \mathrm{IC}_{50}=500 \mathrm{nM} \text { (BzATP- and } \\
\text { induced dye uptake) }\end{array}$ & $\begin{array}{l}\text { Rat peritoneal } \\
\text { macrophages }\end{array}$ & {$[24]$} \\
\hline Emodin & $\mathrm{P} 2 \mathrm{X} 7$ & $\begin{array}{l}\text { Inhibits } \mathrm{ATP} / \mathrm{BzATP} \text {-activated } \mathrm{P} 2 \mathrm{X} 7 \\
\text { receptor } \mathrm{IC}_{50}=3.4 \mu \mathrm{M} \\
\text { (BzATP-evoked current) }\end{array}$ & HEK 293 & {$[24]$} \\
\hline
\end{tabular}


Table 1. Cont.

\begin{tabular}{|c|c|c|c|c|}
\hline Compound & $\begin{array}{l}\text { Receptor } \\
\text { Type }\end{array}$ & Effects $\left(\mathrm{IC}_{50} / \mathbf{E C}_{50}\right) *$ & Tested Model & Reference \\
\hline $\begin{array}{l}\text { Rheedia.longifolia } \\
\text { methanol extract }\end{array}$ & $\mathrm{P} 2 \mathrm{X} 7$ & $\begin{array}{l}\text { Inhibits } \mathrm{P} 2 \mathrm{X} 7 \text { receptor-associated } \\
\text { pore opening, currents and dye uptake } \\
\text { functional assay } \mathrm{IC}_{50}=2 \mu \mathrm{g} / \mathrm{mL} \\
\text { (functional assay) }\end{array}$ & $\begin{array}{l}\text { Mouse peritoneal } \\
\text { macrophages }\end{array}$ & {$[25]$} \\
\hline $\begin{array}{l}\text { Flavonoid } \\
\text { molecules }\end{array}$ & $\mathrm{P} 2 \mathrm{Y} 2$ & $\begin{array}{l}\text { Potent antagonism and inhibition of } \\
\text { intracellular calcium release ND }\end{array}$ & NG108-15 cells & {$[26]$} \\
\hline $\begin{array}{l}\text { Trigonella foenum } \\
\text { leaf extract }\end{array}$ & $\begin{array}{l}\text { P2Y12 } \\
(?)\end{array}$ & $\begin{array}{l}\text { Inhibition of ADP-induced platelets } \\
\text { aggregation } \mathrm{IC}_{50}=1.28 \mathrm{mg} / \mathrm{mL}\end{array}$ & Rabbit platelets & {$[27]$} \\
\hline $\begin{array}{l}\text { Trigonella foenum } \\
\text { leaf extract }\end{array}$ & $\mathrm{P} 2 \mathrm{X}$ & $\begin{array}{l}\text { Inhibits } \alpha, \beta \text {-methylene-ATP }(30 \mu \mathrm{M}) \\
\text { induced isometric contraction } \\
\mathrm{IC}_{50}=1.57 \mathrm{mg} / \mathrm{mL}\end{array}$ & Mouse vas deferens & {$[27]$} \\
\hline Colchicine & $\mathrm{P} 2 \mathrm{X} 7$ & $\begin{array}{l}\text { Inhibits } \mathrm{P} 2 \mathrm{X} 7 \text { receptor-associated } \\
\text { pore opening } \mathrm{EC}_{50}=290 \mu \mathrm{M}\end{array}$ & Xenopus laevis oocytes & {$[28]$} \\
\hline Colchicine & $\mathrm{P} 2 \mathrm{X} 7$ & $\begin{array}{l}\text { Inhibits } \mathrm{P} 2 \mathrm{X} 7 \text { receptor-associated } \\
\text { pore opening } \mathrm{EC}_{50}=540 \mu \mathrm{M}\end{array}$ & $\begin{array}{l}\text { Peritoneal mouse } \\
\text { macrophages }\end{array}$ & {$[28]$} \\
\hline
\end{tabular}

$* \mathrm{EC}_{50}=$ half maximal effective concentration; $\mathrm{IC}_{50}=$ half maximal inhibitory concentration; $\mathrm{ND}=$ Not Determinated; $\mathrm{MO}=$ Mustard oil; BzATP = 3'-O-(4-benzoyl)benzoyl adenosine 5'-triphosphate.

$\mathrm{P} 2 \mathrm{X} 2 / 3$ (heterometric receptor) and $\mathrm{P} 2 \mathrm{X} 3$ receptors in trigeminal subnucleus caudalis are involved in the initiation and maintenance of central sensitization in subnucleus oralis nociceptive neurons induced by mustard oil application to the tooth pulp in anesthetized rats, this effect is possible associated with the neuroplastic changes in receptors NMDA ( $N$-methyl-D-aspartate receptors) [15]. In chronic pain mediated by P2X3 receptors, sodium ferulate, an active principle from Chinese herbal medicine with anti-inflammatory activities, inhibited the nociceptive facilitation of the primary sensory afferent neurons after chronic constriction injury [16,29]. In this context, there are several papers describing the effects of Chinese herbal medicines on $\mathrm{P} 2 \mathrm{X} 3$ and $\mathrm{P} 2 \mathrm{X} 2 / 3$ receptors on reducing pain. The ligustrazine alkaloid tetramethylpyrazine has been studied with analgesic purposes in the context of nociceptive responses [17,18], burn injury pain [19], and neuropathic pain [20] induced by $\alpha, \beta$-methylene-ATP. The burn injury pain transmission mediated by $\mathrm{P} 2 \mathrm{X} 3$ receptor may be reduced by puerarin, which is one of the three major isoflavonoid compounds and has been widely used in treatment of myocardial and cerebral ischemia [30]. Puerarin may also impair the neuropathic pain mediated by $\mathrm{P} 2 \mathrm{X} 3$ receptor in dorsal root ganglion neurons [22].

In 2004, Shemon observed that chelerythrine, a benzophenanthridine alkaloid, blocks the ATPinduced cation fluxes mediated by the P2X7 receptor, as well as the ATP induced stimulation of phospholipase D in human B lymphocytes [31]. Said, in 2007, described the in vitro and in vivo toxicity of four vegetable oils compared to castor oil to validate their use as vehicles of lipophilic drugs in eye drops [32]. P2X7 receptor activation was a parameter analyzed to assess the cytotoxicity induced by these oils. They observed that only castor oil promoted P2X7 receptor activation. In addition, Coutinho-Silva's group investigated the effect of mineral oil and thioglycolate, substances capable of recruiting macrophages into mouse peritoneal cavity, on P2X7 receptor expression and function. They found that mineral oil induced P2X7 down regulation associated with reduced 
functional activity of this receptor [33]. In the paper published by Liu and colleagues in 2010, the authors studied the anti-inflammatory and immunosuppressive mechanisms of emodin (1,3,8-trihydroxy-6methylanthraquinone), an anthraquinone derivative from Rheum officinale Baill. The P2X7 receptor activities induced by ATP or BzATP were inhibited by emodin pre-treatment in native macrophages or transfected HEK-293 cells with P2X7R [24]. Interestingly, emodin was able to impair P2X2/3 receptor role in transmission of neuropathic pain stimuli of primary sensory neurons in Sprague-Dawley rats [23]. Santos and coworkers have demonstrated that the extract and fractions of Rheedia longifolia inhibited the P2X7 receptor-induced dye uptake and ionic currents. After chromatography analysis, they identified the bisflavonoids as the most probable active compounds responsible for P2X7 inhibitory effects present in the R. longifolia extract and fractions [25].

The Colchicum sp. secondary metabolite colchicine is traditionally associated with gout treatment because of its ability to disturb cytoskeletal microfilaments, inhibiting inflammatory cell activation. Marques-da-Silva and colleagues showed that in vitro dolchicine was able to inhibit pore opening, but not the P2X7 receptor low-conductance channel. Furthermore, dolchicine also diminished the maturation and release of IL- $1 \beta$ and production of nitric oxide and reactive oxygen species induced by ATP. Interestingly, these effects were specific to dolchicine and were not found with other mitotic inhibitors, such as taxol and vincristine [28].

In relation to P2Y receptors, Mendes and colleagues, in 2003, observed P2Y1 or P2Y2 receptors' participation in the mechanism of the vascular relaxation produced by polyphenolic substances from red wine [34]. Kaulich and colleagues evaluated a series of 40 flavonoids as antagonists at P2Y2 receptors expressed in NG108-15 cells. By measuring the inhibition of UTP-stimulated intracellular calcium release, they identified diverse flavonoids as potent antagonists at $\mathrm{P} 2 \mathrm{Y} 2$ receptors, with $\mathrm{IC}_{50}$ values in the low micromolar range and potency similar or higher than the standard P2Y2 antagonists Reactive Blue 2 and Suramin [26]. Polyphenolic compounds extracted from Aronia melanocarpa fruits have been reported to be cardioprotective agents. The Luzak group examined the ability of Aronia melanocarpa extract to increase the efficacy of human umbilical vein endothelial cells to inhibit platelet functions in vitro. They observed that only at low concentrations $(5 \mu \mathrm{g} / \mathrm{mL}) \mathrm{did}$ Aronia melanocarpa extract significantly improve antiplatelet action of human umbilical vein endothelial cells towards ADP-activated platelets in the aggregation test [35]. In another work, ADP-activated platelet aggregation was inhibited by ethyl acetate extract from Opuntia humifusa raf. This extract inhibited ADP-induced intracellular calcium mobilization and ATP release [36].

Parvizpur and collaborators observed that Trigonella foenum (TFG) leaf extract can exert analgesic effects in both formalin and tail flick tests [37,38]. In another paper [27], they studied the involvement of purinergic receptors in the formalin and tail flick tests. The TFG extract $[0.5,1,1.5,3 \mathrm{mg} / \mathrm{mL}]$ inhibited ADP $\left[10^{-5} \mathrm{~mol}\right]$ induced platelet aggregation $\left[\mathrm{IC}_{50}=1.28 \mathrm{mg} / \mathrm{mL}\right] . \alpha, \beta$-methylene-ATP $[30 \mathrm{mM}]$ induced isometric contraction in the vas deferens was inhibited by Suramin, a P2 receptor antagonist or TFG extract [ $\mathrm{IC}_{50}$ were $91.07 \mu \mathrm{M}$ and $1.57 \mathrm{mg} / \mathrm{mL}$, respectively].

\section{Natural Products from Animal Sources Acting on P2 Receptors}

Animal sources of natural products have received less attention in the search for discovering new medicines. Nevertheless, new medicines, most of which are of invertebrate origin, have been approved 
for human use. According to Table 2, there are sixteen purified compounds from animal origin, which are discussed below.

Table 2. Natural products from animal sources.

\begin{tabular}{|c|c|c|c|c|c|}
\hline Compound & $\begin{array}{l}\text { Receptor } \\
\text { Type }\end{array}$ & Source & Effects $\left(\mathrm{IC}_{50} / \mathrm{EC}_{50}\right) *$ & Tested Model & Reference \\
\hline Halistanol & \multirow{3}{*}{ P2Y12 } & \multirow{3}{*}{ Topsentia sp. } & Binds to $\mathrm{P} 2 \mathrm{Y} 12$ receptor & $1321 \mathrm{~N}$ cells & [39] \\
\hline & & & & & \\
\hline $\begin{array}{l}\text { Sterol sulfate } \\
\text { Sch } 572423\end{array}$ & & & $\begin{array}{l}\text { Binds to } \mathrm{P} 2 \mathrm{Y} 12 \text { receptor } \\
\mathrm{IC}_{50}=2.2 \mu \mathrm{M}\end{array}$ & $1321 \mathrm{~N}$ cells & [39] \\
\hline Iso-iantheran-A & P2Y11 & $\begin{array}{l}\text { Ianthella } \\
\text { quadrangulata }\end{array}$ & $\begin{array}{l}\text { Activates } \mathrm{P} 2 \mathrm{Y} 11 \text { receptor } \\
\mathrm{EC}_{50}=1.29 \mu \mathrm{M}\end{array}$ & $\begin{array}{l}\text { 1321N1 wild-type } \\
\text { cells }\end{array}$ & [40] \\
\hline Iso-iantheran-B & P2Y11 & $\begin{array}{l}\text { Ianthella } \\
\text { quadrangulata }\end{array}$ & $\begin{array}{l}\text { Activates } \mathrm{P} 2 \mathrm{Y} 11 \text { receptor } \\
\mathrm{EC}_{50}=0.48 \mu \mathrm{M}\end{array}$ & $\begin{array}{l}\text { 1321N1 wild-type } \\
\text { cells }\end{array}$ & [40] \\
\hline Stylissadines A & \multirow{2}{*}{$\mathrm{P} 2 \mathrm{X} 7$} & \multirow{2}{*}{$\begin{array}{l}\text { Stylissa } \\
\text { flabellata }\end{array}$} & $\begin{array}{l}\text { Inhibits BzATP-induced pore } \\
\text { formation } \mathrm{IC}_{50}=0.7 \mu \mathrm{M}\end{array}$ & $\begin{array}{l}\text { THP-1 cells. } \\
\text { (Human Monocytes) }\end{array}$ & [41] \\
\hline Stylissadines B & & & $\begin{array}{l}\text { Inhibits BzATP-induced pore } \\
\text { formation } \mathrm{IC}_{50}=1.8 \mu \mathrm{M}\end{array}$ & THP-1 cells & [41] \\
\hline Niphatoxin C & $\mathrm{P} 2 \mathrm{X} 7$ & $\begin{array}{l}\text { Callyspongia } \\
\text { sp. }\end{array}$ & $\begin{array}{l}\text { Impairment of } \mathrm{P} 2 \mathrm{X} 7 \text { receptor } \\
\text { activity ND }\end{array}$ & THP-1 cells & [42] \\
\hline LL37 & $\mathrm{P} 2 \mathrm{X} 7$ & $\begin{array}{l}\text { Human } \\
\text { neutrophils and } \\
\text { epithelial cells }\end{array}$ & $\begin{array}{l}\text { Induces IL- } 1 \beta \text { maturation and } \\
\text { release in LPS-primed } \\
\text { monocytes ND }\end{array}$ & Human monocytes & [43] \\
\hline rCRAMP & $\mathrm{P} 2 \mathrm{Y}$ & $\begin{array}{l}\text { Ratus } \\
\text { novergicus }\end{array}$ & $\begin{array}{l}\text { Induction of IL- } 6 \text { expression and } \\
\text { ERK } 1 / 2 \text { in glial cells, blocked } \\
\text { by P2Y receptor antagonists ND }\end{array}$ & Rat glial cells & [44] \\
\hline CRAMP & $\mathrm{P} 2 \mathrm{X} 7$ & Mus musculus & $\begin{array}{l}\text { Inhibition of all responses related } \\
\text { to } \mathrm{P} 2 \mathrm{X} 7 \text { activation ND }\end{array}$ & $\begin{array}{l}\text { Peritoneal } \\
\text { macrophages }\end{array}$ & [45] \\
\hline $\begin{array}{l}\text { Cellular prion } \\
\text { protein }\end{array}$ & $\mathrm{P} 2 \mathrm{X} 4$ & Homo sapiens & $\begin{array}{l}\text { Prevents and reverses } \\
\text { Copper-inhibited ATP-evoked } \\
\text { current } \mathrm{EC}_{50}=4.6 \mu \mathrm{M}\end{array}$ & $\begin{array}{l}\text { Xenopus laevis } \\
\text { oocyte }\end{array}$ & [46] \\
\hline Melittin & $\begin{array}{l}\mathrm{P} 2 \mathrm{X} 2 / 3 \\
\text { and } \\
\mathrm{P} 2 \mathrm{X} 3\end{array}$ & $\begin{array}{l}\text { Apitoxin (bee } \\
\text { venom) }\end{array}$ & $\begin{array}{l}\text { Antagonists of both receptor } \\
\text { suppressed melittin-evoked } \\
\text { persistent spontaneous } \\
\text { nociception ND }\end{array}$ & $\begin{array}{l}\text { Male Sprague- } \\
\text { Dawley albino rats } \\
\text { weighing } 180-250 \mathrm{~g}\end{array}$ & [47] \\
\hline $\begin{array}{l}\text { Alphadefensin } \\
1-3\end{array}$ & $\mathrm{P} 2 \mathrm{Y} 6$ & $\begin{array}{l}\text { Human } \\
\mathrm{CD} 14^{-} / \mathrm{CD} 24^{+} \\
\text {cells }\end{array}$ & $\begin{array}{l}\text { Inhibits M-CSF-induced } \\
\text { differentiation of CD14/CD } 24^{+} \\
\text {cells through P2Y6 receptor ND }\end{array}$ & $\begin{array}{l}\mathrm{CD} 14^{+} / \mathrm{CD} 24^{-} \\
\text {monocytes human } \\
\text { cells }\end{array}$ & [48] \\
\hline $\begin{array}{l}\Omega \text {-Conotoxin } \\
\text { GVIA }\end{array}$ & $\mathrm{P} 2 \mathrm{X} 2 / 3$ & Conus sp. & $\begin{array}{l}\text { Inhibits } \mathrm{P} 2 \mathrm{X} 2 / 3 \text { receptor } \\
\text { response } \mathrm{IC}_{50}=3.84 \mu \mathrm{M} \\
\text { Inhibits } \mathrm{P} 2 \mathrm{X} 3 \text { receptor response } \\
\mathrm{IC}_{50}=21.2 \mathrm{nM}\end{array}$ & $\begin{array}{l}\text { Rat dorsal root } \\
\text { ganglion neurons } \\
\text { Rat dorsal root } \\
\text { ganglion neurons }\end{array}$ & [49] \\
\hline Purotoxin-1 & $\mathrm{P} 2 \mathrm{X}$ & Lycosa spider & $\begin{array}{l}\text { Inhibition of ionic currents in the } \\
\text { sensory neurons of rats ND }\end{array}$ & $\begin{array}{l}\text { Rat dorsal root } \\
\text { ganglion neurons }\end{array}$ & {$[50]$} \\
\hline Purotoxin-1 & $\mathrm{P} 2 \mathrm{X} 3$ & $\begin{array}{l}\text { Geolycosa sp. } \\
\text { spider venom }\end{array}$ & Potent inhibitory effects ND & Sensory neurons & [51] \\
\hline
\end{tabular}

$* \mathrm{EC}_{50}=$ half maximal effective concentration; $\mathrm{IC}_{50}=$ half maximal inhibitory concentration; $\mathrm{ND}=$ Not Determinated. 
Several research groups consider marine organisms as a reliable source of new drugs. On par with this idea, a diverse array of compounds obtained from marine animals are under clinical trials [52]. Bioassay-guided fractionation of an active fraction of the marine sponge Topsentia sp. (Halichondriidae) obtained from a marine fraction library led to the isolation and identification of halistanol sulfate and of a new sterol sulfate compound, denominated Sch 572423. Both compounds inhibited the P2Y12 receptor [39]. Greve and collaborators isolated three new iantherans (iso-iantheran A, 8-carboxy-iso-iantheran A, and iso-iantheran B) composed of a rare dimeric benzofuran skeleton, including a 2,3-dihydroxy-1,3-butadiene disulfate moiety, obtained from the marine sponge, Ianthella quadrangulata. Biological assays demonstrated an agonist effect of iso-iantheran-A and iso-iantheran-B on P2Y11 receptors with $\mathrm{EC}_{50}$ values of $1.29 \mu \mathrm{M}$ and $0.48 \mu \mathrm{M}$, respectively [40].

In 2007, Buchanan and colleagues [41] published three papers on P2X7 receptor function, based on a natural product high throughput screening effort to discover selective P2X7 receptor antagonists using marine sponge derivatives. Initially, they observed that the Australian marine sponge Stylissa flabellata was related to the blockage on the cationic current trough the P2X7 receptors by benzophrenatridins alkaloids (stylissadines A and B). This action was not selective however, and they noted the inhibition of some enzymes by this phytochemistry compound, such as protein kinase $\mathrm{C}$ and alanine aminotransferase. Both compounds inhibited $\mathrm{P} 2 \mathrm{X} 7$ receptor function with $\mathrm{IC}_{50}$ values of $0.7 \mu \mathrm{M}$ and $1.8 \mu \mathrm{M}$, respectively [41]. In another paper, these authors used the Australian marine sponge Callyspongia sp. (Callyspongiidae) and isolated the bioactive constituents the Niphatoxin C, which belongs to the 3-alkylpyridinium class of alkaloids. This constituent impaired the P2X7 receptor activity on THP-1 cells [42].

Melittin is the principal active component of apitoxin (bee venom) and is a powerful stimulator of phospholipase A2. The subcutaneous injection of melittin could induce persistent spontaneous nociception and primary thermal or mechanical hyperalgesia, but the exact peripheral mechanisms remain unclear. Post-treatment of the primary injury site with subcutaneous injection of A-317491 (P2X3 and P2X2/3 receptor antagonist) and Reactive Blue 2 (general P2Y receptor antagonist) suppressed the melittin-evoked persistent spontaneous nociception and hypersensitivity (thermal and mechanical) responses [47].

Grishin and colleagues demonstrated that the spider venom purotoxin-1 can inhibit P2X3 receptor function and delay the recovery rate from its desensitization [51]. Moreover, this 35-amino acid single-chain peptide also down regulates primary afferent sensory neurons leading to antinociceptive states with attractive $12 \mathrm{nM}$ concentration. It is noteworthy that the concentration of purotoxin-1 was 3-fold lower than the P2X3 and P2X2/3 receptor antagonist A-317491, which encourages development of novel pain killer drugs. In 2009, Savchenko and colleagues studied the modulatory effect of peptide compounds of Lycosa spider venom on the ionic currents in the sensory neurons of rats through P2X receptors in rat dorsal root ganglion neurons [50].

Antimicrobial peptides (also called host defense peptides) are an evolutionarily conserved component of the innate immune response and are found among all classes of organisms. In general, these peptides are potent, broad-spectrum antibiotics, but in some cases, as we describe below, these peptides may modulate the ionic channels.

The human cathelicidin-derived peptide LL37 is a potent antimicrobial peptide produced predominantly by neutrophils and epithelial cells. LPS-primed monocytes stimulated with LL37 lead 
to the maturation and release of interleukin-1beta (IL-1beta) via the P2X7 receptor. IL-1beta release and cell permeability were suppressed by pretreatment with the P2X7 receptor inhibitors oxidized ATP, KN04, and KN62 [43]. LPS-primed monocytes, stimulated with LL37, resulted in P2X7 receptor maturation and release of IL-beta.

Another peptide, the antibacterial cathelicidin rCRAMP (homologue of the human LL-37), not only exhibits potent bactericidal activities in rats, but also functions as a chemoattractant for immune cells. Brandenburg and colleagues [44] showed that rCRAMP-induced IL-6 expression and ERK1/2 phosphorylation in glial cells. This effect might be mediated by P2Y11 and was not mediated by P2X receptors since those that block the P2X receptors did not affect the production of IL-6. On the other hand, Seil and collaborates described that CRAMP, also in mice, inhibited all the responses coupled to $\mathrm{P} 2 \mathrm{X} 7$ receptors in macrophages [45].

Another family of peptides denominated as conotoxins, which belong to a group of neurotoxic peptides isolated from the venom of the marine cone snail, genus Conus, was found to modulate several types of ionic channels, including N-type calcium channels, which selectively act in the ascending pain pathway [53,54]. Extracted from Conus snails, $\Omega$-conotoxin GVIA inhibits P2X3 and $\mathrm{P} 2 \mathrm{X} 2 / 3$ receptor-mediated responses with $\mathrm{IC}_{50}$ values of $21.2 \mathrm{nM}$ and $3.84 \mu \mathrm{M}$, respectively [49].

The human alpha-defensin 1-3, which is a small arginine-rich peptide, participates in the host immune defense, and is secreted by $\mathrm{CD} 14^{-} / \mathrm{CD} 24^{+}$cells. This peptide has been shown to inhibit macrophage-colony stimulating factor induced differentiation of $\mathrm{CD} 14^{-} / \mathrm{CD} 24^{+}$cells, at least in part through P2Y6, a receptor involved in macrophage differentiation [48].

Cellular prion protein physiological function remains unknown, but there is evidence supporting its role in copper homeostasis. Lorca and his group have shown that the perfusion of this domain prevents and reverses the inhibition by $\mathrm{Cu}^{2+}$ of ATP-evoked currents of the $\mathrm{P} 2 \mathrm{X} 4$ receptor subtype, highlighting a modulatory role for cellular prion protein in synaptic transmission through regulation of $\mathrm{Cu}^{2+}$ levels [46].

\section{Natural Products from Microorganisms Acting on P2 Receptors}

Substances produced by microorganisms that modulate tissues, cell types, and protein function, have long been known as shown in Table 3. To this effect, ivermectin, a semisynthetic derivative of the natural fermentation products of Streptomyces avermitilis, is widely used in human and veterinary medicine as an antiparasitic agent [55]. In 1999, Khakh showed that ivermectin is a specific positive allosteric effector of heterologously expressed P2X4, but not of P2X2, P2X3, P2X2/3, or P2X7 receptor channels in rats [56]. This result was confirmed by other groups in humans [57], mice [58], and rats [59]. Recently, however, Nörenberg et al. 2012 [60] described a positive allosteric effector of ivermectin also on human $\mathrm{P} 2 \mathrm{X} 7$ receptor.

The natural peptide polymyxin B is a well-known and potent antibiotic that binds and neutralizes bacterial endotoxin lipopolysaccharide. Ferrari demonstrated that polymyxin B increased the responses mediated by the P2X7 receptor in HEK293 and K562 cell lines transfected with P2X7 receptor cDNA, as well as in mouse and human macrophages [61]. 
Table 3. Natural products from microorganism product sources.

\begin{tabular}{|c|c|c|c|c|c|}
\hline Compound & $\begin{array}{l}\text { Receptor } \\
\text { Type }\end{array}$ & Source & $\begin{array}{l}\text { Effects } \\
\left(\mathrm{IC}_{50} / \mathrm{EC}_{50}\right)\end{array}$ & Tested Model & Reference \\
\hline Ivermectin & $\mathrm{P} 2 \mathrm{X} 4$ & Streptomyces avermitilis & $\begin{array}{l}\text { Positive allosteric effect } \\
\mathrm{EC}_{50}=250 \mathrm{nM}\end{array}$ & $\begin{array}{l}\text { Xenopus laevis } \\
\text { oocyte }\end{array}$ & {$[56]$} \\
\hline Ivermectin & $\mathrm{P} 2 \mathrm{X} 4$ & Streptomyces avermitilis & $\begin{array}{l}\text { Blockage of ethanol-inhibitory } \\
\text { effects ND }\end{array}$ & $\begin{array}{l}\text { Xenopus laevis } \\
\text { oocyte }\end{array}$ & {$[62]$} \\
\hline Ivermectin & $\mathrm{P} 2 \mathrm{X} 7$ & Streptomyces avermitilis & $\begin{array}{l}\text { Positive allosteric effect } \\
\mathrm{EC}_{50}=50 \mathrm{nM}\left(\mathrm{EC}_{50} \text { from high }\right. \\
\text { affinity-binding site })\end{array}$ & $\begin{array}{l}\text { Macrophage } \\
\text { from humans }\end{array}$ & {$[60]$} \\
\hline Polymyxin B & $\mathrm{P} 2 \mathrm{X} 7$ & Bacillus polymyxa & $\begin{array}{l}\text { Enhanced } \mathrm{P} 2 \mathrm{X} 7 \text { responses in } \\
\text { transfected-HEK } 293 \text { and K562 cells ND }\end{array}$ & $\begin{array}{l}\text { Mouse and } \\
\text { human } \\
\text { macrophage cells }\end{array}$ & {$[61]$} \\
\hline Pfiesteriatoxin & $\mathrm{P} 2 \mathrm{X} 7$ & Pfiesteriapiscicida & $\begin{array}{l}\text { Activation of cell permeabilization } \\
\text { similarly to ATP activation ND }\end{array}$ & $\begin{array}{l}\text { GH4C1 rat } \\
\text { pituitary cells }\end{array}$ & {$[63]$} \\
\hline Pfiesteriatoxin & $\mathrm{P} 2 \mathrm{X} 7$ & Pfiesteriapiscicida & $\begin{array}{l}\text { Induction of toxic and c-fos luciferase } \\
\text { that is blocked by oxATP and PPADS } \\
\text { ND }\end{array}$ & $\begin{array}{l}\text { GH4C1 rat } \\
\text { pituitary cells }\end{array}$ & {$[64]$} \\
\hline HlyA & $\begin{array}{l}\mathrm{P} 2 \mathrm{X} 1 \text { and } \\
\mathrm{P} 2 \mathrm{X} 7\end{array}$ & Escherichia coli & $\begin{array}{l}\text { Antagonists of both receptor blocked } \\
\text { HlyA induced hemolysis ND }\end{array}$ & $\begin{array}{l}\text { Human, mouse } \\
\text { and equine } \\
\text { Erythrocytes }\end{array}$ & {$[65]$} \\
\hline $\begin{array}{l}\text { Cytotoxic } \\
\text { factors }\end{array}$ & $\mathrm{P} 2 \mathrm{X} 7$ & $\begin{array}{l}\text { Pseudomonas } \\
\text { aeruginosastrain } 808\end{array}$ & $\begin{array}{l}\text { P2X7 receptor participation in } \\
\text { ATP-dependent pathway ND }\end{array}$ & $\begin{array}{l}\text { J774 macrophage } \\
\text { cell line }\end{array}$ & {$[66]$} \\
\hline Leukotoxin & $\mathrm{P} 2 \mathrm{X} 7$ & $\begin{array}{l}\text { Aggregatibacter } \\
\text { actinomycetemcomitans }\end{array}$ & $\begin{array}{l}\text { Leukotoxin-induced proinflammatory } \\
\text { responses, release of IL-1 } \beta \text { and IL-18 } \\
\text { are blocked by oxATP ND }\end{array}$ & $\begin{array}{l}\text { Human } \\
\text { macrophages }\end{array}$ & {$[67]$} \\
\hline Oxo-AHL & $\begin{array}{l}\mathrm{P} 2 \mathrm{Y} 2 \text { and } \\
\mathrm{P} 2 \mathrm{Y} 4\end{array}$ & Pseudomonasaeruginosa & $\begin{array}{l}\text { Inhibits } \mathrm{P} 2 \mathrm{Y} 2 \text { and } \mathrm{P} 2 \mathrm{Y} 4 \text { expression in } \\
\text { cystic fibrosis } \mathrm{IC}_{50}=0.3 \mathrm{pM}\end{array}$ & $\begin{array}{l}\text { HTGS cell line } \\
\text { MM39 }\end{array}$ & {$[68]$} \\
\hline LPS & $\mathrm{P} 2 \mathrm{X} 7$ & Gram-negative bacteria & $\begin{array}{l}\text { P2X7 receptor modulates } \\
\text { LPS-induced responses ND }\end{array}$ & $\begin{array}{l}\text { Murine } \\
\text { Peritoneal } \\
\text { Macrophages }\end{array}$ & [69] \\
\hline LPS & $\mathrm{P} 2 \mathrm{X} 7$ & Gram-negative bacteria & $\begin{array}{l}\text { P2X7 receptor inhibition in } \\
\text { TLR-4-defficient cell ND }\end{array}$ & HEK293 cells & {$[70]$} \\
\hline LPS & P2Y6 & Gram-negative bacteria & $\begin{array}{l}\text { Vascular inflammation following } \\
\text { selective induction of endothelial P2Y6 } \\
\text { receptor ND }\end{array}$ & HMEC-1 & [71] \\
\hline LOS & $\mathrm{P} 2 \mathrm{X}$ & Gram-negative bacteria & $\begin{array}{l}\text { Inhibition of } \mathrm{P} 2 \mathrm{X} \text { receptor decrease } \\
\text { LOS-induced caspase- } 8 \text { activation and } \\
\text { apoptosis ND }\end{array}$ & $\begin{array}{l}\text { Primary bovine } \\
\text { pulmonary artery } \\
\text { endothelial cells }\end{array}$ & {$[72]$} \\
\hline
\end{tabular}

$* \mathrm{EC}_{50}=$ half maximal effective concentration; $\mathrm{IC}_{50}=$ half maximal inhibitory concentration; ND $=$ Not Determinated; LOS $=$ Lipooligosaccharide.

Pfiesteria piscicida is a dinoflagellate that produces the putative bioactive substance Pfiesteria toxin, which displays toxicity in fishes and humans. This substance induced cell permeabilization in a similar manner as ATP in culture of GH4C1 rat pituitary cells expressing functional P2X7 receptors. 
This effect was inhibited by the P2X7 receptor antagonist oxidized ATP [63]. In addition, Kimm-Brinson examined the pharmacological activity of the Pfiesteria toxin on the signaling pathway that induces the $c$-fos luciferase construct in GH4C1 rat pituitary cells. ATP-, BZATP-, and Pfiesteria toxin-induced cytotoxicity, and c-fos luciferase activity was inhibited by pyridoxalphosphate-6azophenyl-2',4'-disulfonic acid and the P2X7 irreversible antagonist oxidized-ATP [64].

Escherichia coli, which exhibits facultative and invasive strains, is the dominant facultative bacterium in the normal intestinal flora, but it is also responsible for the majority of serious extraintestinal infections. Alpha-hemolysin (HlyA) is a virulence factor produced by invasive E. coli strains, which causes hemolysis by forming pores in the erythrocyte membrane and triggers purinergic receptor activation to mediate the full hemolytic action. General P2 antagonists (pyridoxalphosphate-6azophenyl-2',4'-disulfonic acid and suramin) and ATP scavengers (apyrase, hexokinase) inhibited HlyA-induced lysis of equine, murine, and human erythrocytes. P2X1 and P2X7 receptors antagonists indicated both receptors to be involved in the HlyA-induced hemolysis [65].

Cytotoxic factors released by a nonmucoid clinical isolate of Pseudomonas aeruginosa, strain 808, produced ATP-dependent and -independent responses. The ATP dependent pathway utilizes the P2X7 receptor to exert its effects, in contrast to the ATP-independent pathway [66].

Aggregatibacter (Actinobacillus) actinomycetemcomitans is a facultative anaerobic Gram-negative bacterium associated with severe forms of periodontitis and several virulence factors. Among those, the leukotoxin is suggested to have an important role in its pathogenicity $[73,74]$. This toxin is able to lyse human immune cells and induces significant secretion of the pro-inflamatory cytokines IL-1 and IL-18 in human macrophages $[67,75]$. This pro-inflammatory response was inhibited by oxidized ATP, which indicates the involvement of the $\mathrm{P} 2 \mathrm{X} 7$ receptor [67].

Cystic fibrosis is a genetic disease characterized by the hypersecretion of mucus, inflammation in the airways, and especially by persistent severe bacterial infections, generally by the gram-negative bacterium Pseudomonas aeruginosa [76]. ATP or UTP analogues were shown to induce chloride secretion by cystic fibrosis epithelial cells [77] and also to induce bronchial relaxation [78]. $P$. aeruginosa virulence factors can be regulated by two unique quorum sensing systems [79] composed by a small diffusible signal molecule ( $N$-acylhomoserine lactone [AHL]) and a transcriptional activator protein [80]. In this work, the authors tested the effects of AHLs on HTGS cells regarding its action upon $\mathrm{P} 2$ receptors. Oxo-AHLs treatments repressed the stimulatory effects of secretory leukocyte proteinase inhibitor secretion by nucleotides, possibly due to the repression of P2Y2 and P2Y4 receptor expression, in cystic fibrosis but not normal HTGS cells [68].

Components of gram-negative bacteria have been studied in the context of the purinergic signaling in inflammation processes that promote an increase of nucleotide concentrations. The bacterial endotoxin LPS is one of the strongest stimuli for the immune response, and several papers have shown that P2X7 receptor activation can modulate LPS-induced responses [69,81]. Interestingly, a binding site for LPS within the P2X7 receptor C-terminus has been proposed. Accordingly, Leiva-Salcedo and colleagues investigated if LPS can directly modulate the activity of the P2X7 receptor. They found that LPS alone was unable to induce any P2X7 receptor-related activity, suggesting that the receptor is not directly activated by the endotoxin. On the other hand, pre-application of LPS inhibited P2X7 receptor ionic channel and pore function in HEK293 cells [70]. Compellingly, another bacterial product lipooligosacharide also is able to promote the release of ATP and its derivatives, which can enhance 
the processes of cell activation and apoptosis. These lipid A-containing compounds stimulate endothelial cells to take part in several inflammatory steps, such as production and release of reactive oxygen species, cytokine, and again, the "universal" danger-associated molecule pattern, ATP [72].

Some microorganisms, such as yeast and bacteria, are capable of producing alcohols; as such, the effect of short alcohols was described [82,83]. ATP-activated ionic currents in presynaptic and postsynaptic membranes, due to $\mathrm{P} 2 \mathrm{X} 4$ and $\mathrm{P} 2 \mathrm{X} 2$ receptor activation, were reduced by ethanol treatment [83]. In 2011, Ostrovskaya demonstrated that ethanol inhibits ATP-gated currents mediated by $\mathrm{P} 2 \mathrm{X} 4$ receptor in a rapid manner, and the inhibition does not depend on voltage or ATP concentration [84].

In another paper, Asatryan showed that ivermectin may reverse the inhibitory effects of ethanol in P2X4 receptor in dose-dependent manner [62]. Fischer and collaborates demonstrated that P2X3, a receptor widely expressed in dorsal root ganglion neurons, seems to be distinctly modulated by 2,2,2-thicloroethanol. As compared to ethanol, 2,2,2-thicloroethanol inhibited current responses and intracellular calcium elevation of ATP and its analogue $\alpha, \beta$-methylene-ATP [85]. Davies, in 2005, transfected the $\mathrm{hP} 2 \mathrm{X} 3$ and $\mathrm{hP} 2 \mathrm{X} 4$ receptors to Xenopus oocytes and studied the ionic current after ATP treatment. Ethanol reduced P2X4 receptor responses and increased the maximal response of $\mathrm{P} 2 \mathrm{X} 3$ receptor ionic currents [86].

During a systemic inflammatory response, endothelial-expressed surface molecules have been strongly implicated in regulating immune responses. Based on previous studies about exhibiting enhanced extracellular nucleotide released during acute inflammation, Riegel postulated that endothelial nucleotide receptors could play a role in vascular inflammation. Pharmacologic or genetic in vivo studies showed attenuated inflammatory responses in $\mathrm{P}^{\mathrm{Y} \sigma^{/-}}$mice or after P2Y6 antagonist treatment during LPS-induced vascular inflammation [71].

\section{Conclusions}

The association of diseases with expression of purinergic receptors should prompt further search for pharmacological compounds with selective action on $\mathrm{P} 2 \mathrm{X}$ and $\mathrm{P} 2 \mathrm{Y}$ receptors. Accordingly, the results described here revealed that several promising natural products present significant agonist or antagonist activities for $\mathrm{P} 2$ receptors. A better understanding of the role of $\mathrm{P} 2$ receptors in physiological and pathological processes will be a key element in the discovery of new medicines for several pathological conditions such as cancer, rheumatoid arthritis, and pain.

\section{Acknowledgments}

This work was supported by grants from FAPERJ, CNPq, PAPES V/Fiocruz-CNPq, and Oswaldo Cruz Institute. We are grateful to Vinicius Cotta de Almeida for helpful discussions and suggestions.

\section{References}

1. Musselman, L. Encyclopedia of Common Natural Ingredients Used in Food, Drugs, and Cosmetics; John Wiley \& Sons: New York, NY, USA, 1996; p. 422. 
2. Butler, M.S. The role of natural product chemistry in drug discovery. J. Nat. Prod. 2004, 67, 2141-2153.

3. Ley, S.V.; Baxendale, I.R. New tools and concepts for modern organic synthesis. Nat. Rev. Drug Discov. 2002, 1, 573-586.

4. Geysen, H.M.; Schoenen, F.; Wagner, D.; Wagner, R. Combinatorial compound libraries for drug discovery: an ongoing challenge. Nat. Rev. Drug Discov. 2003, 2, 222-230.

5. Lombardino, J.G.; Lowe, J.A. The role of the medicinal chemist in drug discovery-Then and now. Nat. Rev. Drug Discov. 2004, 3, 853-862.

6. Portales-Cervantes, L.; Niño-Moreno, P.; Doníz-Padilla, L.; Baranda-Candido, L.; García-Hernández, M.; Salgado-Bustamante, M.; González-Amaro, R.; Portales-Pérez, D. Expression and function of the $\mathrm{P} 2 \mathrm{X}(7)$ purinergic receptor in patients with systemic lupus erythematosus and rheumatoid arthritis. Hum. Immunol. 2010, 71, 818-825.

7. Inoue, K. P2 receptors and chronic pain. Purinergic Signal. 2007, 3, 135-144.

8. Tsuda, M.; Tozaki-Saitoh, H.; Inoue, K. Pain and purinergic signaling. Brain Res. Rev. 2010, 63, 222-232.

9. White, N.; Burnstock, G. P2 receptors and cancer. Trends Pharmacol. Sci. 2006, 27, 211-217.

10. Guile, S.D.; Alcaraz, L.; Birkinshaw, T.N.; Bowers, K.C.; Ebden, M.R.; Furber, M.; Stocks, M.J. Antagonists of the $\mathrm{P} 2 \mathrm{X}(7)$ receptor. From lead identification to drug development. J. Med. Chem. 2009, 52, 3123-3141.

11. Boeynaems, J.M.; Communi, D.; Gonzalez, N.S.; Robaye, B. Overview of the P2 receptors. Semin. Thromb. Hemost. 2005, 31, 139-149.

12. Lazarowski, E.R.; Boucher, R.C.; Harden, T.K. Mechanisms of release of nucleotides and integration of their action as P2X- and P2Y-receptor activating molecules. Mol. Pharmacol. 2003, 64, 785-795.

13. Virginio, C.; MacKenzie, A.; Rassendren, F.A.; North, R.A.; Surprenant, A. Pore dilation of neuronal P2X receptor channels. Nat. Neurosci. 1999, 2, 315-321.

14. Faria, R.X.; Defarias, F.P.; Alves, L.A. Are second messengers crucial for opening the pore associated with P2X7 receptor? Am. J. Physiol. Cell Physiol. 2005, 288, C260-C271.

15. Hu, B.; Chiang, C.Y.; Hu, J.W.; Dostrovsky, J.O.; Sessle, B.J. P2X receptors in trigeminal subnucleus caudalis modulate central sensitization in trigeminal subnucleus oralis. J. Neurophysiol. 2002, 88, 1614-1624.

16. Zhang, A.; Gao, Y.; Zhong, X.; Xu, C.; Li, G.; Liu, S.; Lin, J.; Li, X.; Zhang, Y.; Liu, H.; et al. Effect of sodium ferulate on the hyperalgesia mediated by $\mathrm{P} 2 \mathrm{X} 3$ receptor in the neuropathic pain rats. Brain Res. 2010, 1313, 215-221.

17. Liang, S.D.; Gao, Y.; Xu, C.S.; Xu, B.H.; Mu, S.N. Effect of tetramethylpyrazine on acute nociception mediated by signaling of P2X receptor activation in rat. Brain Res. 2004, 995, 247-252.

18. Liang, S.D.; Xu, C.S.; Zhou, T.; Liu, H.Q.; Gao, Y.; Li, G. L. Tetramethylpyrazine inhibits ATP-activated currents in rat dorsal root ganglion neurons. Brain Res. 2005, 1040, 92-97.

19. Gao, Y.; Xu, C.; Yu, K.; Li, G.; Wan, F.; Liu, S.; Lin, J.; Liu, H.; Zhang, J.; Li, X.; et al. Effect of tetramethylpyrazine on DRG neuron $\mathrm{P} 2 \mathrm{X} 3$ receptor involved in transmitting pain after burn. Burns 2010, 36, 127-134. 
20. Gao, Y.; Liang, S.D.; Shao, L.J.; Mu, S.N.; Xu, C.S.; Zhang, C.P. Effect of tetramethylpyrazine on neuropathic pain mediated by $\mathrm{P} 2 \mathrm{X} 3$ receptor. Acta Pharmacol. Sin. 2006, 77, 27-32.

21. Xu, C.; Li, G.; Gao, Y.; Liu, S.; Lin, J.; Zhang, J.; Li, X.; Liu, H.; Liang, S. Effect of puerarin on P2X3 receptor involved in hyperalgesia after burn injury in the rat. Brain Res. Bull. 2009, 80, 341-346.

22. Xu, C.; Xu, W.; Xu, H.; Xiong, W.; Gao, Y.; Li, G.; Liu, S.; Xie, J.; Tu, G.; Peng, H.; et al. Role of puerarin in the signalling of neuropathic pain mediated by P2X3 receptor of dorsal root ganglion neurons. Brain Res. Bull. 2012, 87, 37-43.

23. Gao, Y.; Liu, H.; Deng, L.; Zhu, G.; Xu, C.; Li, G.; Liu, S.; Xie, J.; Liu, J.; Kong, F.; et al. Effect of emodin on neuropathic pain transmission mediated by $\mathrm{P} 2 \mathrm{X} 2 / 3$ receptor of primary sensory neurons. Brain Res. Bull. 2011, 84, 406-413.

24. Liu, L.; Zou, J.; Liu, X.; Jiang, L.H.; Li, J. Inhibition of ATP-induced macrophage death by emodin via antagonizing P2X7 receptor. Eur. J. Pharmacol. 2010, 640, 15-19.

25. Santos, J.A.; Fidalgo-Neto, A.A.; Faria, R.X.; Simões, A.; Calheiros, A.S.; Bérenger, A.L.; Faria-Neto, H.C.; Figueiredo, M.R.; Frutuoso, V.S.; Alves, L.A. Effect of Rheedia longifolia leaf extract and fractions on the $\mathrm{P}_{2} \mathrm{X}_{7}$ receptor in vitro: novel antagonists? J. Med. Food 2011, 14, 920-929.

26. Kaulich, M.; Streicher, F.; Mayer, R.; Müller, I.; Müller, C.E. Flavonoids-Bovel lead compounds for the development of P2Y2 receptor antagonists. 2003, 59, 72-81.

27. Parvizpur, A.; Ahmadiani, A.; Kamalinejad, M. Probable role of spinal purinoceptors in the analgesic effect of Trigonella foenum (TFG) leaves extract. J. Ethnopharmacol. 2006, 104, 108-112.

28. Marques-da-Silva, C.; Chaves, M.M.; Castro, N.G.; Coutinho-Silva, R.; Guimaraes, M.Z. Colchicine inhibits cationic dye uptake induced by ATP in P2X2 and P2X7 receptor-expressing cells: implications for its therapeutic action. Br. J. Pharmacol. 2011, 163, 912-926.

29. Zhang, A.; Xu, C.; Liang, S.; Gao, Y.; Li, G.; Wei, J.; Wan, F.; Liu, S.; Lin, J. Role of sodium ferulate in the nociceptive sensory facilitation of neuropathic pain injury mediated by $\mathrm{P} 2 \mathrm{X}(3)$ receptor. Neurochem. Int. 2008, 53, 278-282.

30. Gao, Y.; Xu, C.; Liang, S.; Zhang, A.; Mu, S.; Wang, Y.; Wan, F. Effect of tetramethylpyrazine on primary afferent transmission mediated by $\mathrm{P} 2 \mathrm{X} 3$ receptor in neuropathic pain states. Brain Res. Bull. 2008, 77, 27-32.

31. Shemon, A.N.; Sluyter, R.; Conigrave, A.D.; Wiley, J.S. Chelerythrine and other benzophenanthridine alkaloids block the human P2X7 receptor. Br. J. Pharmacol. 2004, 142, 1015-1019.

32. Said, T.; Dutot, M.; Christon, R.; Beaudeux, J.L.; Martin, C.; Warnet, J.M.; Rat, P. Benefits and side effects of different vegetable oil vectors on apoptosis, oxidative stress, and P2X7 cell death receptor activation. Invest. Ophthalmol. Vis. Sci. 2007, 48, 5000-5006.

33. Marques da Silva, C.; Miranda Rodrigues, L.; Passos da Silva Gomes, A.; Mantuano Barradas, M.; Sarmento Vieira, F.; Persechini, P.M.; Coutinho-Silva, R. Modulation of P2X7 receptor expression in macrophages from mineral oil-injected mice. Immunobiology 2008, 213, 481-492.

34. Mendes, A.; Desgranges, C.; Chèze, C.; Vercauteren, J.; Freslon, J.L. Vasorelaxant effects of grape polyphenols in rat isolated aorta. Possible involvement of a purinergic pathway. Fundam. Clin. Pharmacol. 2003, 17, 673-681. 
35. Luzak, B.; Golanski, J.; Rozalski, M.; Krajewska, U.; Olas, B.; Watala, C. Extract from Aronia melanocarpa fruits potentiates the inhibition of platelet aggregation in the presence of endothelial cells. Arch. Med. Sci. 2010, 6, 141-144.

36. Oh, W.-J.; Endale, M.; Park, J.-Y.; Kwak, Y.-S.; Kim, S.; Kim, G.-S.; Rhee, M.H. The inhibitory effect of Opuntia humifusa Raf. Ethyl acetate extract on platelet aggregation. J. Med. Plants Res. 2011, 5, 1418-1424.

37. Ahmadiani, A.; Javan, M.; Semnanian, S.; Barat, E.; Kamalinejad, M. Anti-inflammatory and antipyretic effects of Trigonella foenum-graecum leaves extract in the rat. J. Ethnopharmacol. 2001, 75, 283-286.

38. Javan, M.; Ahmadiani, A.; Semnanian, S.; Kamalinejad, M. Antinociceptive effects of Trigonella foenum-graecum leaves extract. J. Ethnopharmacol. 1997, 58, 125-129.

39. Yang, S.W.; Buivich, A.; Chan, T.M.; Smith, M.; Lachowicz, J.; Pomponi, S.A.; Wright, A.E.; Mierzwa, R.; Patel, M.; Gullo, V.; et al. A new sterol sulfate, Sch 572423, from a marine sponge, Topsentia sp. Bioorg. Med. Chem. Lett. 2003, 13, 1791-1794.

40. Greve, H.; Meis, S.; Kassack, M.U.; Kehraus, S.; Krick, A.; Wright, A.D.; König, G.M. New iantherans from the marine sponge Ianthella quadrangulata: novel agonists of the P2Y(11) receptor. J. Med. Chem. 2007, 50, 5600-5607.

41. Buchanan, M.S.; Carroll, A.R.; Addepalli, R.; Avery, V.M.; Hooper, J.N.; Quinn, R.J. Natural products, stylissadines $\mathrm{A}$ and $\mathrm{B}$, specific antagonists of the $\mathrm{P} 2 \mathrm{X} 7$ receptor, an important inflammatory target. J. Org. Chem. 2007, 72, 2309-2317.

42. Buchanan, M.S.; Carroll, A.R.; Addepalli, R.; Avery, V.M.; Hooper, J.N.; Quinn, R.J. Niphatoxin C, a cytotoxic tripyridine alkaloid from Callyspongia sp. J. Nat. Prod. 2007, 70, 2040-2041.

43. Elssner, A.; Duncan, M.; Gavrilin, M.; Wewers, M.D. A novel P2X7 receptor activator, the human cathelicidin-derived peptide LL37, induces IL-1 beta processing and release. J. Immunol. 2004, 172, 4987-4994.

44. Brandenburg, L.O.; Jansen, S.; Wruck, C.J.; Lucius, R.; Pufe, T. Antimicrobial peptide rCRAMP induced glial cell activation through $\mathrm{P} 2 \mathrm{Y}$ receptor signalling pathways. Mol. Immunol. 2010, 47, 1905-1913.

45. Seil, M.; Kabré, E.; Nagant, C.; Vandenbranden, M.; Fontanils, U.; Marino, A.; Pochet, S.; Dehaye, J.P. Regulation by CRAMP of the responses of murine peritoneal macrophages to extracellular ATP. Biochim. Biophys. Acta 2010, 1798, 569-578.

46. Lorca, R.A.; Chacón, M.; Barría, M.I.; Inestrosa, N.C.; Huidobro-Toro, J.P. The human prion octarepeat fragment prevents and reverses the inhibitory action of copper in the $\mathrm{P} 2 \mathrm{X} 4$ receptor without modifying the zinc action. $J$. Neurochem. 2003, 85, 709-716.

47. Lu, Z.M.; Xie, F.; Fu, H.; Liu, M.G.; Cao, F.L.; Hao, J.; Chen, J. Roles of peripheral P2X and $\mathrm{P} 2 \mathrm{Y}$ receptors in the development of melittin-induced nociception and hypersensitivity. Neurochem. Res. 2008, 33, 2085-2091.

48. Droin, N.; Jacquel, A.; Hendra, J.B.; Racoeur, C.; Truntzer, C.; Pecqueur, D.; Benikhlef, N.; Ciudad, M.; Guery, L.; Jooste, V.; et al. Alpha-defensins secreted by dysplastic granulocytes inhibit the differentiation of monocytes in chronic myelomonocytic leukemia. Blood 2010, 115, $78-88$. 
49. Lalo, U.V.; Pankratov, Y.V.; Arndts, D.; Krishtal, O.A. Omega-conotoxin GVIA potently inhibits the currents mediated by P2X receptors in rat DRG neurons. Brain Res. Bull. 2001, 54, 507-512.

50. Savchenko, H.A.; Vasylevs'kyı̆, A.A.; Pluzhnykov, K.A.; Korol'kova, I.V.; Mamenko, M.V.; Volkova, T.M.; Maksymiuk, O.P.; Boĭchuk, I.A.; Hrishyn, I.V.; Kryshtal', O.O. Peptide components of Geolycosa spider venom modulate P2X receptor activity of rat sensory neurons. Fiziol. Zh. 2009, 55, 11-16.

51. Grishin, E.V.; Savchenko, G.A.; Vassilevski, A.A.; Korolkova, Y.V.; Boychuk, Y.A.; Viatchenko-Karpinski, V.Y.; Nadezhdin, K.D.; Arseniev, A.S.; Pluzhnikov, K.A.; Kulyk, V.B.; et al. Novel peptide from spider venom inhibits P2X3 receptors and inflammatory pain. Ann. Neurol. 2010, 67, 680-683.

52. Faulkner, D.J. Marine natural products. Nat. Prod. Rep. 2001, 18, 1-49.

53. Lewis, R.J.; Dutertre, S.; Vetter, I.; Christie, M.J. Conus venom peptide pharmacology. Pharmacol. Rev. 2012, 64, 259-298.

54. Lewis, R.J.; Nielsen, K.J.; Craik, D.J.; Loughnan, M.L.; Adams, D.A.; Sharpe, I.A.; Luchian, T.; Adams, D.J.; Bond, T.; Thomas, L.; et al. Novel omega-conotoxins from Conus catus discriminate among neuronal calcium channel subtypes. J. Biol. Chem. 2000, 275, 35335-35344.

55. Burkhart, C.N. Ivermectin: an assessment of its pharmacology, microbiology and safety. Vet. Hum. Toxicol. 2000, 42, 30-35.

56. Khakh, B.S.; Proctor, W.R.; Dunwiddie, T.V.; Labarca, C.; Lester, H.A. Allosteric control of gating and kinetics at P2X(4) receptor channels. J. Neurosci. 1999, 19, 7289-7299.

57. Priel, A.; Silberberg, S.D. Mechanism of ivermectin facilitation of human P2X4 receptor channels. J. Gen. Physiol. 2004, 123, 281-293.

58. Sim, J.A.; Park, C.K.; Oh, S.B.; Evans, R.J.; North, R.A. P2X1 and P2X4 receptor currents in mouse macrophages. Br. J. Pharmacol. 2007, 152, 1283-1290.

59. Bowler, J.W.; Bailey, R.J.; North, R.A.; Surprenant, A. P2X4, P2Y1 and P2Y2 receptors on rat alveolar macrophages. Br. J. Pharmacol. 2003, 140, 567-575.

60. Nörenberg, W.; Sobottka, H.; Hempel, C.; Plötz, T.; Fischer, W.; Schmalzing, G.; Schaefer, M. Positive allosteric modulation by ivermectin of human but not murine P2X7 receptors. $\mathrm{Br}$. $J$. Pharmacol. 2012, 167, 48-66.

61. Ferrari, D.; Pizzirani, C.; Adinolfi, E.; Forchap, S.; Sitta, B.; Turchet, L.; Falzoni, S.; Minelli, M.; Baricordi, R.; di Virgilio, F. The antibiotic polymyxin B modulates P2X7 receptor function. J. Immunol. 2004, 173, 4652-4660.

62. Asatryan, L.; Popova, M.; Perkins, D.; Trudell, J.R.; Alkana, R.L.; Davies, D.L., Ivermectin antagonizes ethanol inhibition in purinergic P2X4 receptors. J. Pharmacol. Exp. Ther. 2010, 334, 720-728.

63. Melo, A.C.; Moeller, P.D.; Glasgow, H.; Burkholder, J.M.; Ramsdell, J.S. Microfluorimetric analysis of a purinergic receptor (P2X7) in $\mathrm{GH} 4 \mathrm{C} 1$ rat pituitary cells: effects of a bioactive substance produced by Pfiesteria piscicida. Environ. Health Perspect. 2001, 109 (Suppl 5), 731-737.

64. Kimm-Brinson, K.L.; Moeller, P.D.; Barbier, M.; Glasgow, H.; Burkholder, J.M.; Ramsdell, J.S. Identification of a $\mathrm{P} 2 \mathrm{X} 7$ receptor in $\mathrm{GH}(4) \mathrm{C}(1)$ rat pituitary cells: a potential target for a bioactive substance produced by Pfiesteria piscicida. Environ. Health Perspect. 2001, 109, 457-462. 
65. Skals, M.; Jorgensen, N.R.; Leipziger, J.; Praetorius, H.A. Alpha-hemolysin from Escherichia coli uses endogenous amplification through $\mathrm{P} 2 \mathrm{X}$ receptor activation to induce hemolysis. Proc. Natl. Acad. Sci. USA 2009, 106, 4030-4035.

66. Zaborina, O.; Dhiman, N.; Ling Chen, M.; Kostal, J.; Holder, I.A.; Chakrabarty, A.M. Secreted products of a nonmucoid Pseudomonas aeruginosa strain induce two modes of macrophage killing: external-ATP-dependent, P2Z-receptor-mediated necrosis and ATP-independent, caspase-mediated apoptosis. Microbiology 2000, 146, 2521-2530.

67. Kelk, P.; Abd, H.; Claesson, R.; Sandström, G.; Sjöstedt, A.; Johansson, A. Cellular and molecular response of human macrophages exposed to Aggregatibacter actinomycetemcomitans leukotoxin. Cell Death Dis. 2011, 2, e126.

68. Saleh, A.; Figarella, C.; Kammouni, W.; Marchand-Pinatel, S.; Lazdunski, A.; Tubul, A.; Brun, P.; Merten, M.D. Pseudomonas aeruginosa quorum-sensing signal molecule $\mathrm{N}$-(3-oxododecanoyl)-Lhomoserine lactone inhibits expression of $\mathrm{P} 2 \mathrm{Y}$ receptors in cystic fibrosis tracheal gland cells. Infect. Immun. 1999, 67, 5076-5082.

69. Le Feuvre, R.A.; Brough, D.; Iwakura, Y.; Takeda, K.; Rothwell, N.J. Priming of macrophages with lipopolysaccharide potentiates P2X7-mediated cell death via a caspase-1-dependent mechanism, independently of cytokine production. J. Biol. Chem. 2002, 277, 3210-3218.

70. Leiva-Salcedo, E.; Coddou, C.; Rodríguez, F.E.; Penna, A.; Lopez, X.; Neira, T.; Fernández, R.; Imarai, M.; Rios, M.; Escobar, J.; et al. Lipopolysaccharide inhibits the channel activity of the P2X7 receptor. Mediators Inflamm. 2011, 2011, 152625.

71. Riegel, A.K.; Faigle, M.; Zug, S.; Rosenberger, P.; Robaye, B.; Boeynaems, J.M.; Idzko, M.; Eltzschig, H.K. Selective induction of endothelial P2Y6 nucleotide receptor promotes vascular inflammation. Blood 2011, 117, 2548-2555.

72. Sylte, M.J.; Kuckleburg, C.J.; Inzana, T.J.; Bertics, P.J.; Czuprynski, C.J. Stimulation of P2X receptors enhances lipooligosaccharide-mediated apoptosis of endothelial cells. J. Leukoc. Biol. 2005, 77, 958-965.

73. Kachlany, S.C. Aggregatibacter actinomycetemcomitans leukotoxin: from threat to therapy. J. Dent. Res. 2010, 89, 561-570.

74. Guthmiller, J.M.; Lally, E.T.; Korostoff, J. Beyond the specific plaque hypothesis: Are highly leukotoxic strains of Actinobacillus actinomycetemcomitans a paradigm for periodontal pathogenesis? Crit. Rev. Oral Biol. Med. 2001, 12, 116-124.

75. Johansson, A.; Sandström, G.; Claesson, R.; Hänström, L.; Kalfas, S. Anaerobic neutrophil-dependent killing of Actinobacillus actinomycetemcomitans in relation to the bacterial leukotoxicity. Eur. $J$. Oral Sci. 2000, 108, 136-146.

76. Hata, J.S.; Fick, R.B. Pseudomonas aeruginosa and the airways disease of cystic fibrosis. Clin. Chest Med. 1988, 9, 679-689.

77. Knowles, M.R.; Clarke, L.L.; Boucher, R.C. Activation by extracellular nucleotides of chloride secretion in the airway epithelia of patients with cystic fibrosis. N. Engl. J. Med. 1991, 325, 533-538.

78. Aksoy, M.O.; Kelsen, S.G. Relaxation of rabbit tracheal smooth muscle by adenine nucleotides: mediation by P2-purinoceptors. Am. J. Respir. Cell Mol. Biol. 1994, 10, 230-236. 
79. Latifi, A.; Foglino, M.; Tanaka, K.; Williams, P.; Lazdunski, A. A hierarchical quorum-sensing cascade in Pseudomonas aeruginosa links the transcriptional activators LasR and RhIR (VsmR) to expression of the stationary-phase sigma factor RpoS. Mol. Microbiol. 1996, 21, 1137-1146.

80. Swift, S.; Throup, J.P.; Williams, P.; Salmond, G.P.; Stewart, G.S. Quorum sensing: A population-density component in the determination of bacterial phenotype. Trends Biochem. Sci. 1996, 21, 214-219.

81. Chiao, C.W.; Tostes, R.C.; Webb, R.C. P2X7 receptor activation amplifies lipopolysaccharideinduced vascular hyporeactivity via interleukin-1 beta release. J. Pharmacol. Exp. Ther. 2008, $326,864-870$.

82. Ho, N.W.; Chen, Z.; Brainard, A.P.; Sedlak, M. Successful design and development of genetically engineered Saccharomyces yeasts for effective cofermentation of glucose and xylose from cellulosic biomass to fuel ethanol. Adv. Biochem. Eng. Biotechnol. 1999, 65, 163-192.

83. Davies, D.L.; Machu, T.K.; Guo, Y.; Alkana, R.L. Ethanol sensitivity in ATP-gated P2X receptors is subunit dependent. Alcohol. Clin. Exp. Res. 2002, 26, 773-778.

84. Ostrovskaya, O.; Asatryan, L.; Wyatt, L.; Popova, M.; Li, K.; Peoples, R.W.; Alkana, R.L.; Davies, D.L., Ethanol is a fast channel inhibitor of P2X4 receptors. J. Pharmacol. Exp. Ther. 2011, 337, 171-179.

85. Fischer, W.; Wirkner, K.; Weber, M.; Eberts, C.; Köles, L.; Reinhardt, R.; Franke, H.; Allgaier, C.; Gillen, C.; Illes, P. Characterization of P2X3, P2Y1 and P2Y4 receptors in cultured HEK293-hP2X3 cells and their inhibition by ethanol and trichloroethanol. J. Neurochem. 2003, 85, 779-790.

86. Davies, D.L.; Kochegarov, A.A.; Kuo, S.T.; Kulkarni, A.A.; Woodward, J.J.; King, B.F.; Alkana, R.L. Ethanol differentially affects ATP-gated P2X(3) and P2X(4) receptor subtypes expressed in Xenopus oocytes. Neuropharmacology 2005, 49, 243-253.

(C) 2012 by the authors; licensee MDPI, Basel, Switzerland. This article is an open access article distributed under the terms and conditions of the Creative Commons Attribution license (http://creativecommons.org/licenses/by/3.0/). 